\title{
The Methodology of Applying the Akmeologikal Approach to Education in a Digital Economy Based on Artificial Intelligence
}

\author{
Kirichenko Alexander $\mathrm{V}^{1 *}$, Reznichenko Alexander $\mathrm{V}^{2}$ and Ranepa Zhuk Igor $\mathrm{A}^{2}$ \\ ${ }^{1}$ Doctor of Psychological Sciences, Professor of the Department of personnel management, Russian Federation, Moscow \\ ${ }^{2}$ Department of social, humanitarian, economic and natural Sciences IPNBM, Ranepa \\ *Corresponding author: Kirichenko Alexander V, Doctor of psychological Sciences, Professor of the Department of personnel \\ management, Russian Federation, Moscow
}

\begin{abstract}
An approach to the creation of information technology model of education at the University with the use of artificial intelligence elements is considered.
\end{abstract}

Keywords: Innovative education; Digitalization; Information technologies and elements of artificial intelligence; Learning model

\section{Introduction}

One of the main arguments in favor of the priority role of education in the coming XXI century is the development of scientific and technological progress and global technologization of the advanced countries of the world community. The ongoing global process of formation of a new highly automated information environment of society creates unprecedented opportunities for human development, more effective solutions to its many professional, economic, social and everyday problems. However, only those members of society who possess the necessary knowledge and skills to navigate the new information space will be able to use these opportunities. All this is closely related to the level of development of education. Traditionally, it is believed that education is the process and result of assimilation of systematic knowledge and skills, and the main way of education-training in educational institutions-targeted, organized, systematic and systematically carried out the acquisition of knowledge and skills under the leadership of teachers. And also, traditionally in education, focusing on the object of knowledge, dominated by teaching methods, focused on the transfer of goth knowledge and methods of solving problems of the existing way of life.

However, the basic trend of the development of the modern world-humanity's transition to a post-industrial, technological, information era of development in which a crucial role is played not so much scientific knowledge that describes the world as the technology of its transformation. A post-industrial society needs an innovative economy-an economy based on knowledge, new technologies and human capital. The basis of the progressive development of the economy of each country and of humanity as a whole is the person himself, from whom not only professional knowledge, skills, diligence and discipline are required. His Acmespiritual and moral qualities and culture, creative potential and professional competence, the peak of development, the greatest prosperity of the human personality come to the fore $[1,2]$. Thus, the idea of a new paradigm of higher education-the concept of innovative education (in the terminology of the experts of the club of Rome)-has emerged and is actively developing in modern society. Within the framework of this concept, for an educated person of the XXI century, it is necessary to possess the following basic competencies [3]: communication in the native language; communication in foreign languages; mathematical abilities and basic competencies (skills) in science and technology; information competence; ability to learn.

\section{These Competencies Include the Following Capabilities}

Communication in the native language - is the ability to Express and explain thoughts, feelings and facts both orally and in writing, as well as the appropriate way to linguistically influence a number of social and cultural situations-education and upbringing (training), 
work, home and leisure. Communication in a foreign language, as well as communication in the native language, is based on the ability to understand, Express and interpret thoughts, feelings and facts both orally and in writing in accordance with the social situationat work, at home, during leisure, in education and upbringing (training) in accordance with someone's desires or needs. It provides an opportunity for interpersonal communication. Mathematical competence is the ability to use all mathematical actions in mental and written calculations to solve a number of problems in everyday situations. Essential knowledge in mathematics is a deep knowledge of numbers, measures and structures, basic operations and basic mathematical representations, an understanding of mathematical terms and concepts, as well as those questions that mathematics can answer. Scientific competence implies the ability and willingness to use the basis of knowledge and methodology necessary to explain the natural world.

Competence in technology is represented as the application of knowledge and methodology in response to conscious human desires or needs. The necessary knowledge in science and technology includes the basic principles of the natural world, fundamental scientific concepts, principles and methods, technologies, technological products and processes. Information competence implies confident and critical use of information society technologies for work, leisure and communication. It is complemented by basic skills regarding information and computer technologies: the use of computers for finding, evaluating, storing, producing, presenting and exchanging information, for communication and participation in cooperating networks via the Internet. Learning is the ability to persevere in learning, individually or in groups, by effectively organizing and managing personal time. Competence includes awareness of one's own learning process, needs, identification of available opportunities, ability to remove obstacles in order to learn successfully. This means acquiring, processing and assimilating new knowledge and skills, as well as striving for them. And the most important component of this competence for the Acme of personality is self-actualization (selfrealization) as the desire in its development to fully manifest and use in the activities of their talents, abilities, opportunities in the existing system of social relations. It is considered that by the end of school (primary education) for young people, these core competencies should be developed to a level sufficient for adult life, in order to then be preserved, developed and modernized in accordance with the dynamics of social relations. That is, the need for continuous development of all competencies in modern society puts education on the role of the main resource of social progress, the true capital of each person and humanity as a whole. That is why education is considered as a resource for progressive economic development and a means of ensuring the superiority of the country if the same characteristics that are decisive for the modern innovative economy, post-industrial and information civilization are adequately realized in the sphere of higher education.

\section{These Characteristics Include [4]}

Flexibility and nonlinearity of organizational forms of production and social sphere; inclusion of the processes of obtaining and updating knowledge in all production and social processes reliance on human talent, creativity and initiative as the most important resource of economic and social development multiple changes in technologies (including social ones) in a short period of time, etc. Thus, innovative education should be based on the integration of the most modern and effective technologies of education with intensive research activities; on the connection of University research conducted at the forefront of science, technology, with training and the needs of industry and the economy; on the interdisciplinary nature of education. That is why the President of the Russian Federation V. V. Putin in his message to the Federal Assembly of the Russian Federation dated February 20, 2019 [5] defined as the main priorities not only “... faster growth of labor productivity, primarily on the basis of new technologies and digitalization ..."but also.". training of modern personnel, creation of a powerful scientific and technological base. "However, the digitalization of the economy is not just the transfer of data and processes from the "analog" era to the digital form. And the digitalization of the education system cannot be limited to the creation of a digital copy of the usual textbooks, the digitization of documents and the provision of all schools with access to highspeed Internet as a means of achieving digital literacy.

There are different approaches to the concept and development of digital literacy. For example, Henry Jenkins [6] believes that digital literacy includes the ability to work with computer "iron" (that is, to understand how the interaction between people and digital technology), understanding of peculiarities of structure and distribution of digital information (e.g., ability to work with), understanding of network and community features of social media. Doug Belshaw $[7,8]$ identifies seven elements of digital literacy, including: "understanding the cultural context of the Internet environment, the ability to communicate in online communities, the ability to create and distribute content, the skills of using digital technologies for self-development. "In General, digital literacy should be understood as a set of knowledge and skills that are necessary for life in the modern world, for the safe and effective use of digital technologies and Internet resources. Digital literacy is the ability to create and use content using digital technologies, including work with information and expert systems, artificial intelligence systems; work with large amounts of data ("big data"); computer modeling skills; communication with other people, etc. The development of civilization in the direction of becoming an information society, in which the objects and results of work of the majority of the employed population are not tangible assets, but mainly information and scientific knowledge that forms the additional information technology requirements to the intelligence of every citizen. In this regard, akmeology as a science that studies the laws and mechanisms of human development at the stages of its maturity and especially when it reaches the highest level in this development, should also undergo, in our opinion, significant changes, transforming into digital acmeology-a synergetic science of the laws of achieving maximum perfection of the individual through self-actualization and development of competencies in the field of information technology, artificial intelligence, computer modeling and work with "big data". The object of the study of digital 
akmeology should be the digital economy and digital society as a whole - the environment in which the achievement of the maximum possible level of human perfection is realized. The subject of the study of digital akmeology is the construction of an individual trajectory of human learning to develop skills of self-actualization (self-organization) in the information society.

The implementation of this approach in the General concept of improving the education system of the XXI century is, in our opinion, decisive and requires the solution of a number of common tasks. So, on held in Moscow in January 2019. The Minister of higher education, research and innovation of the French Republic Frederic Vidal noted the special role of combining the Humanities and natural science knowledge in the digital age, the need to implement the project method of teaching and interdisciplinary education, pointed to the lack of qualified personnel who can adapt to a changing world, as part of the current risks of international development, she called the transformation of the entire education system with the use of modern information technologies in General and artificial intelligence methods in particular urgent. Based on the above, the following model of higher Education in the era of the digital economy is proposed (Figure 1).
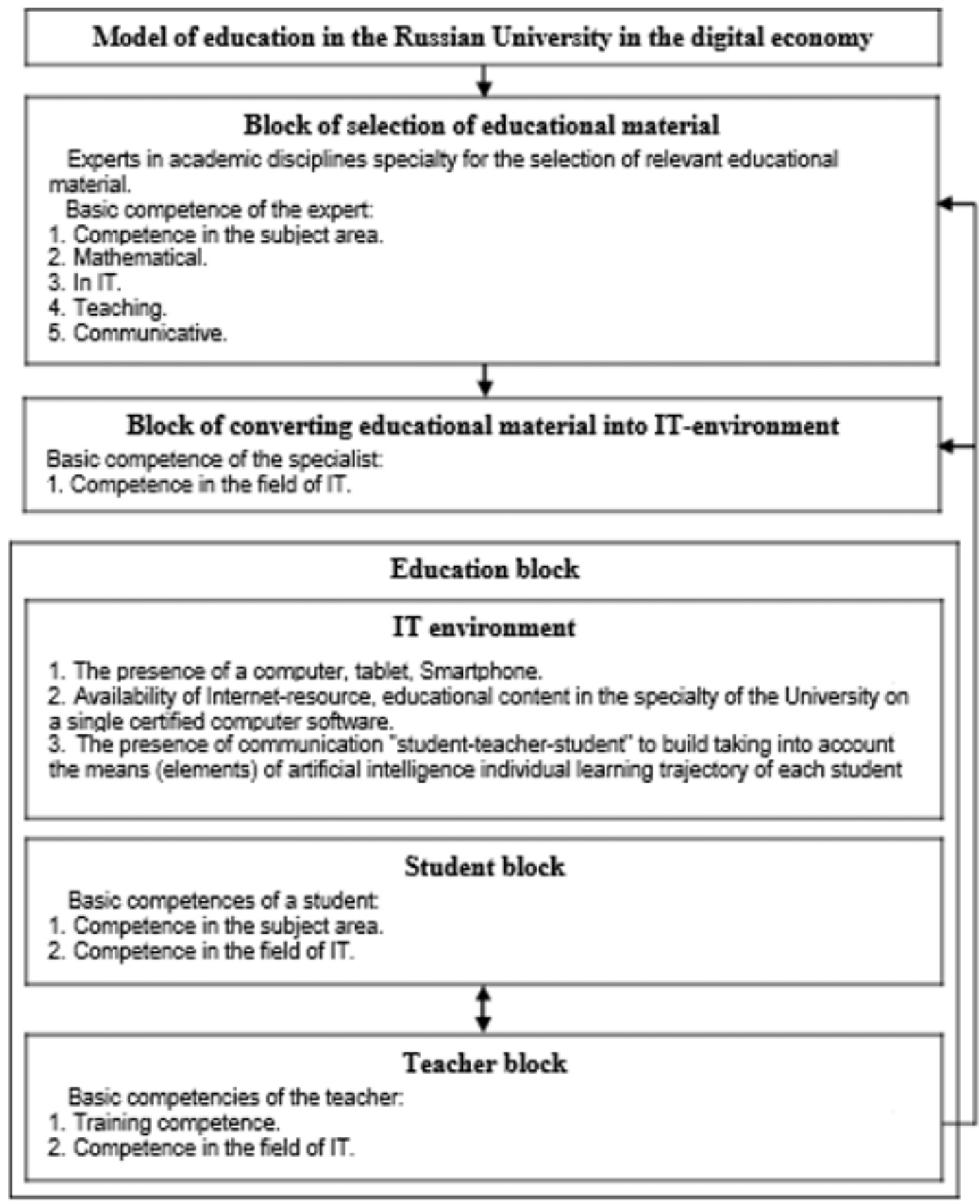

Figure 1: Model of higher Education in the era of digital economy 


\section{Block of Selection of Educational Material}

For the selection of educational material, experts with the competencies presented above, as well as teachers who read the course, are involved. The methods of their work can be very diverse, including the method of analysis of hierarchies [2] to determine the degree of informativeness, ease of assimilation and the relationship of textual, graphic and analytical components of educational content. In turn, the selection of quantitative and qualitative composition of experts is made on the basis of the analysis of the breadth of the problem, the required reliability of estimates, the characteristics of experts and the cost of resources, and assumes the presence of such individual characteristics as: competence-the degree of qualification of an expert in a particular field of knowledge; creativity-the ability to solve creative problems conformism is the susceptibility to influence influencers; attitude to expertise (interest, passive or negative attitude) constructive thinking-the expert should give solutions that have the property of practicality; collectivism-ethics of behavior in the team affects the creation of a positive psychological climate in the team and thus the success of the problem; self-criticism of the expert is manifested in the self-assessment of the degree of its competence, as well as taking into account the opinions of other experts and making decisions on the problem under consideration. The process of selection of experts, complex in itself, involves further questioning of experts, processing of expert assessments and determination of their consistency of experts, which makes the first stage one of the most important.

\section{Unit Conversion of Educational Material IT Environment}

Specialists who convert selected by experts and teacher's educational material into an electronic product, use a variety of IT technologies. So, most teachers for the preparation of lecture material apply office application MS PowerPoint. This program is available, popular, has many opportunities to create interactive lectures. There are other program packages of this level that implement educational information technologies. We can refer to them, for example: Macromedia Director; DemoShield; Authorware. As modern software products that allow teachers to create e-learning include: Articulate Storyline; Moodle; Docebo; Geenio. Analysis of the capabilities of these software packages [3] allowed us to identify iSpring as the most effective for the implementation of the proposed learning model. The result of the conversion of educational content using the iSpring package is a system of frames of complex structure, where the information block is presented: text, graphics and multimedia objects (pictures, audio and video materials), mathematical dependencies, as well as controls for working with the frame (Figure 2). In addition to the traditional navigation elements ("Back", "Next", "Finish"), the student is given the opportunity to vary the size of the information field for the convenience of working with content. On completion of the frame the student is provided the opportunity thrilled to terisolasi degree of understanding (perception) of the materials information block using a binary scale of assessments, implemented on the frame in a drop-down list. This information, as well as the time of work with the material will be automatically transferred to the teacher for subsequent control of the student and the organization of the necessary assistance (feedback). In addition to the information and control frames, it is planned to create test frames for each information block. When forming the test (Figure 3), the IT specialist relies on the opinion of the teacher about the specific content of the information block of the lecture frame to be checked, and the type of test (binary choice, choice "one of many", multiple choice, etc.). The results are aggregated by the teacher in the result for the entire lecture material. Information technology aspects of collecting, aggregating and structuring information about the training model will be considered in the block of the teacher.

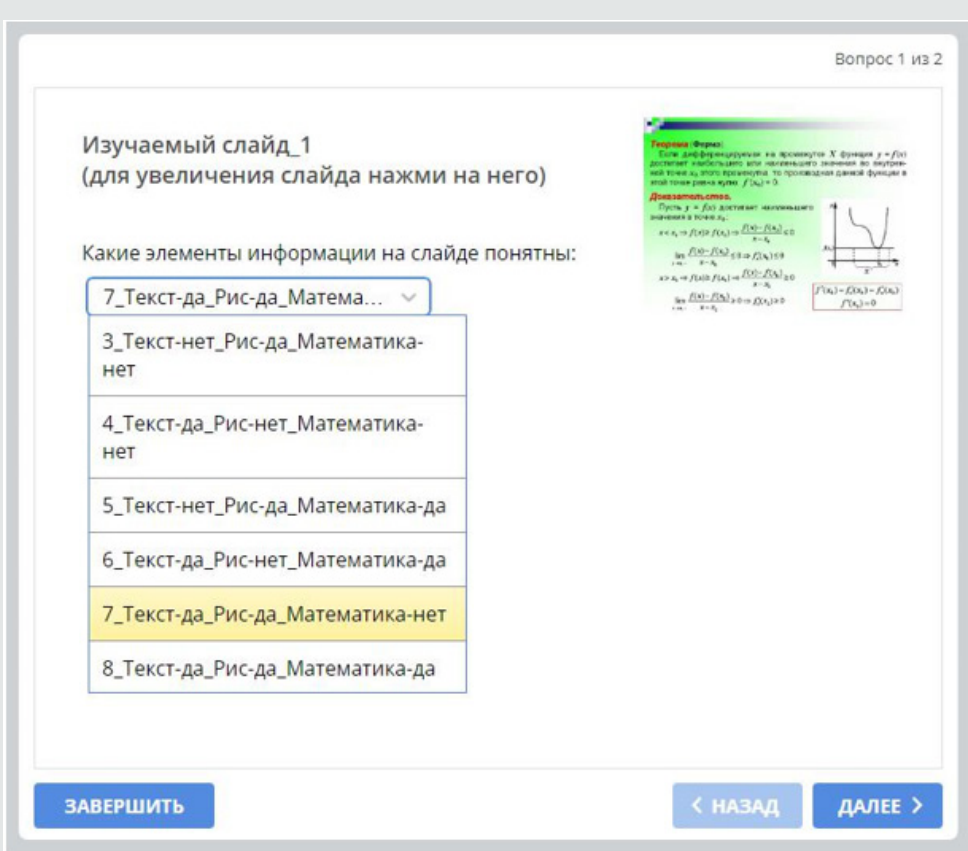

Figure 2: Information and control frame interface in the I Spring package. 


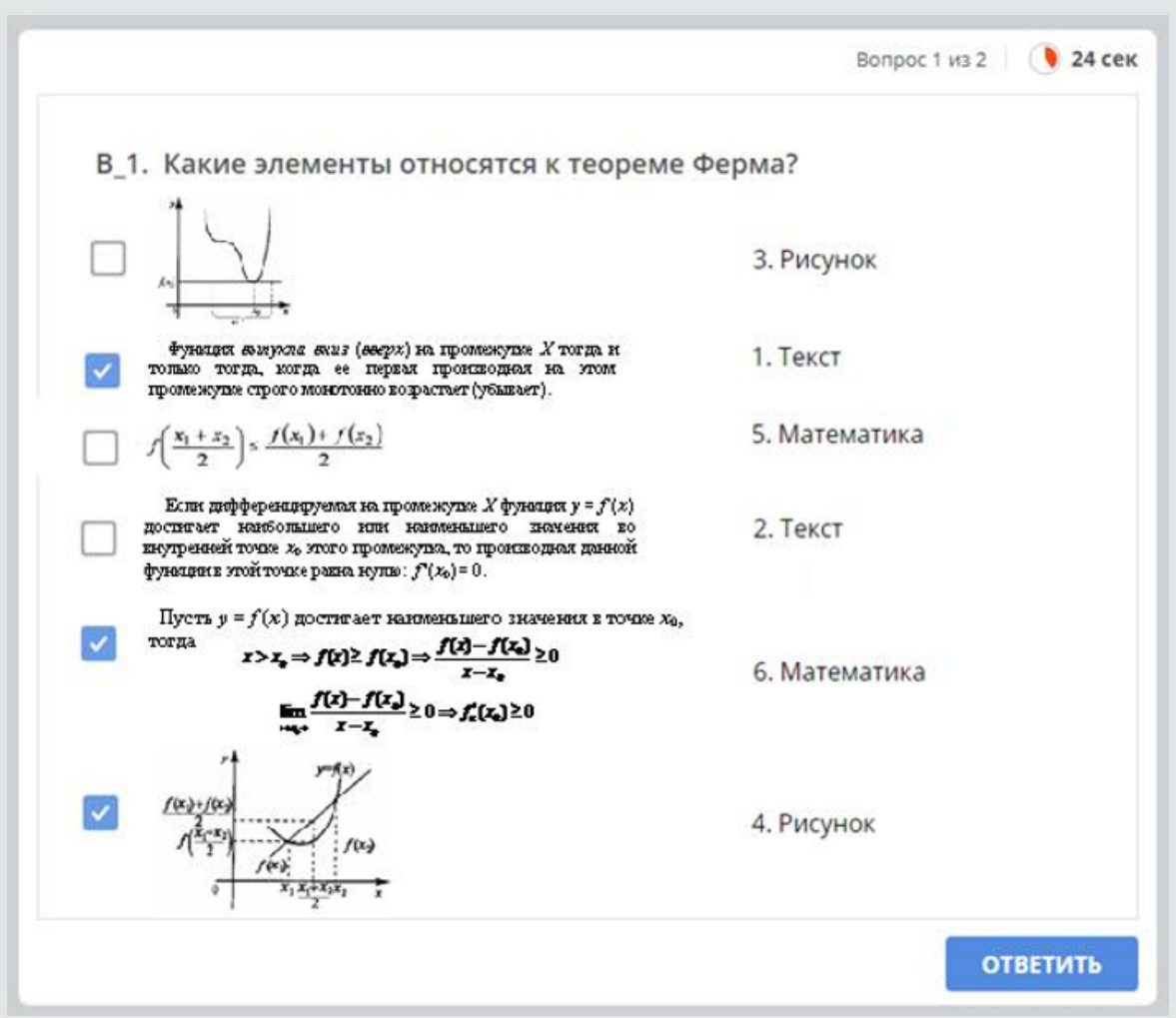

Figure 3: The text frame interface in the I Spring package.

\section{Student Block}

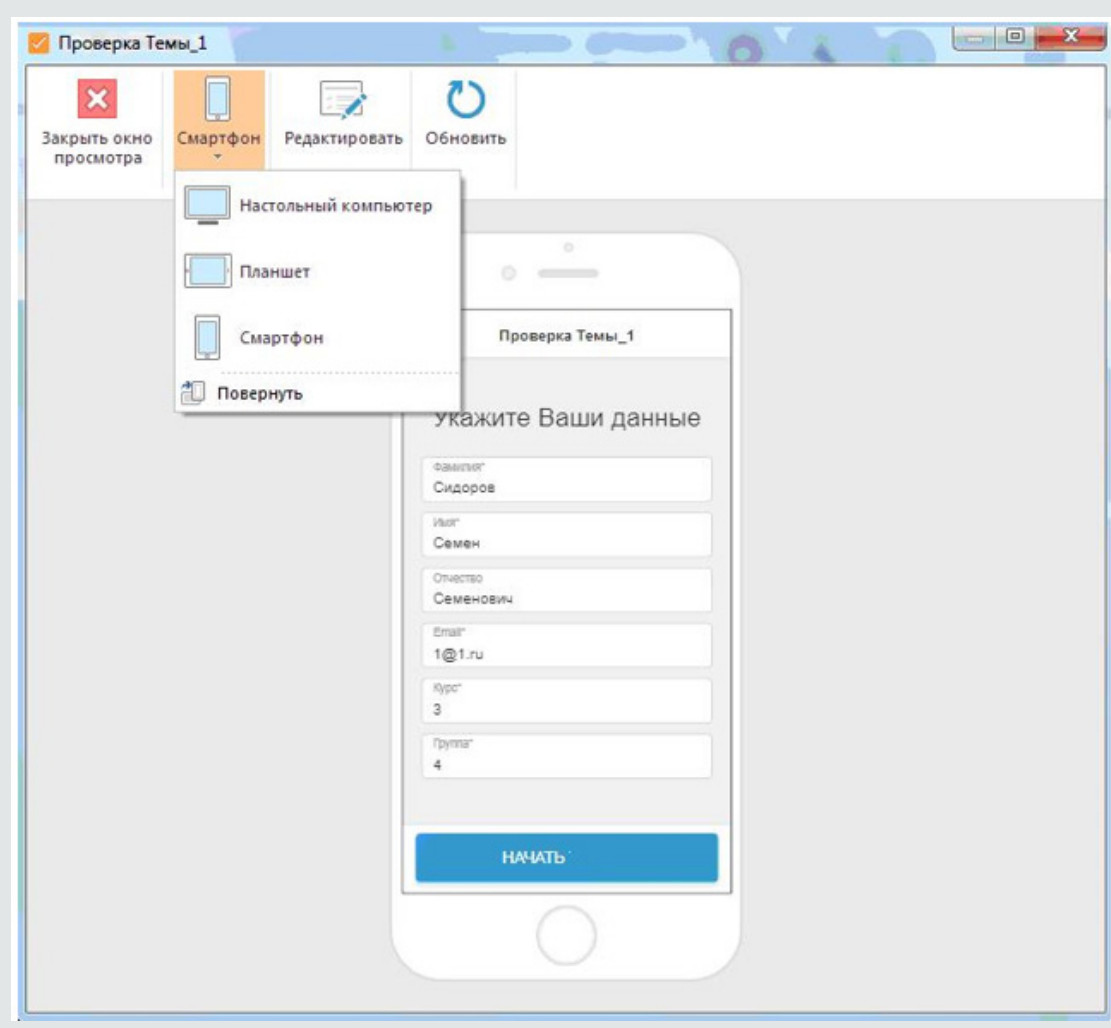

Figure 4: Selection of individual means of work and identification of the student 
The student's work with the educational material requires the presence of an IT environment, and the student must possess the above competencies. Since the proposed software product has elements of feedback, any reference to it begins with the identification of the learner and the choice of an individual means of work and communication, since the software package iSpring allows the variability of terminal devices (Figure 4). The further order and technology of the student's work with the software package is determined by the frame interface and includes: working with the material, understanding its content by types of information, self-assessment ("understood-did not understand" and what exactly-(Figure 2)), passing the test and further movement along the trajectory of the lecture material study. Identification of the student enables the teacher not only to collect and compile data on the degree of understanding the materials information block (self-learner) and test (objective assessment of his knowledge), but also to link their comparative analysis with specific student for the formation of individual trajectory of studying the lecture materials Another advantage of the use of this software is its invariance with respect to the technical means used by students, which provides not only the mode of self-study (self-development) of the student, but also allows lectures in any classrooms equipped with multimedia or remotely. The only requirement is the availability of the Internet.

\section{Block Teacher}

The work of the teacher with the educational material also certainly involves the presence of the IT environment and the possession of competencies in the subject area, as well as in the field of Internet technologies. The latter is necessary for the processing of files sent by trainees and involves the ability to work with e-mail messages and knowledge of MS Office programs. The first stage of the work is the collection and processing of information about the tasks performed by students (self-assessment), which automatically goes to the teacher's e-mail in a formalized form (Figure 5). In the previous version of the iSpring package for data processing, it was necessary to place the message text in a txt file for subsequent transfer to a database formed as an excel file [3]. The transfer was carried out with the help of the program developed by the authors (I. A. Zhuk) on VBA. In the modern version of the iSpring package, this procedure is improved by the developers of the company: the text of the mail message already has excel-formalization and does not require the use of intermediate files for transfer to the database. However, the transfer itself is also carried out using a specially designed macro (Figures 6 \& 7), the content of which is not given due to the limited size of the article.

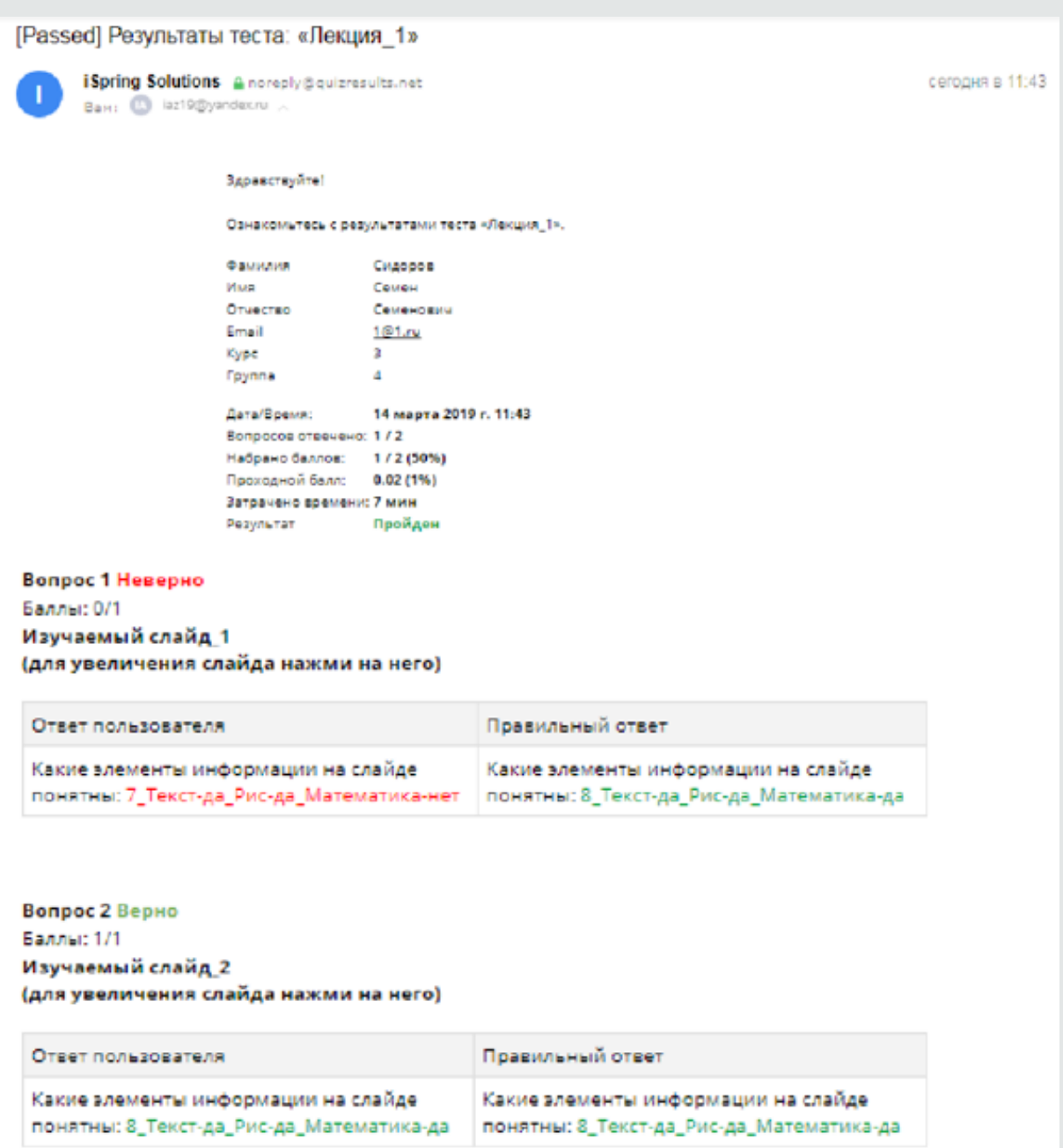

Figure 5: The results of the student's work with lecture materials in the mail. 

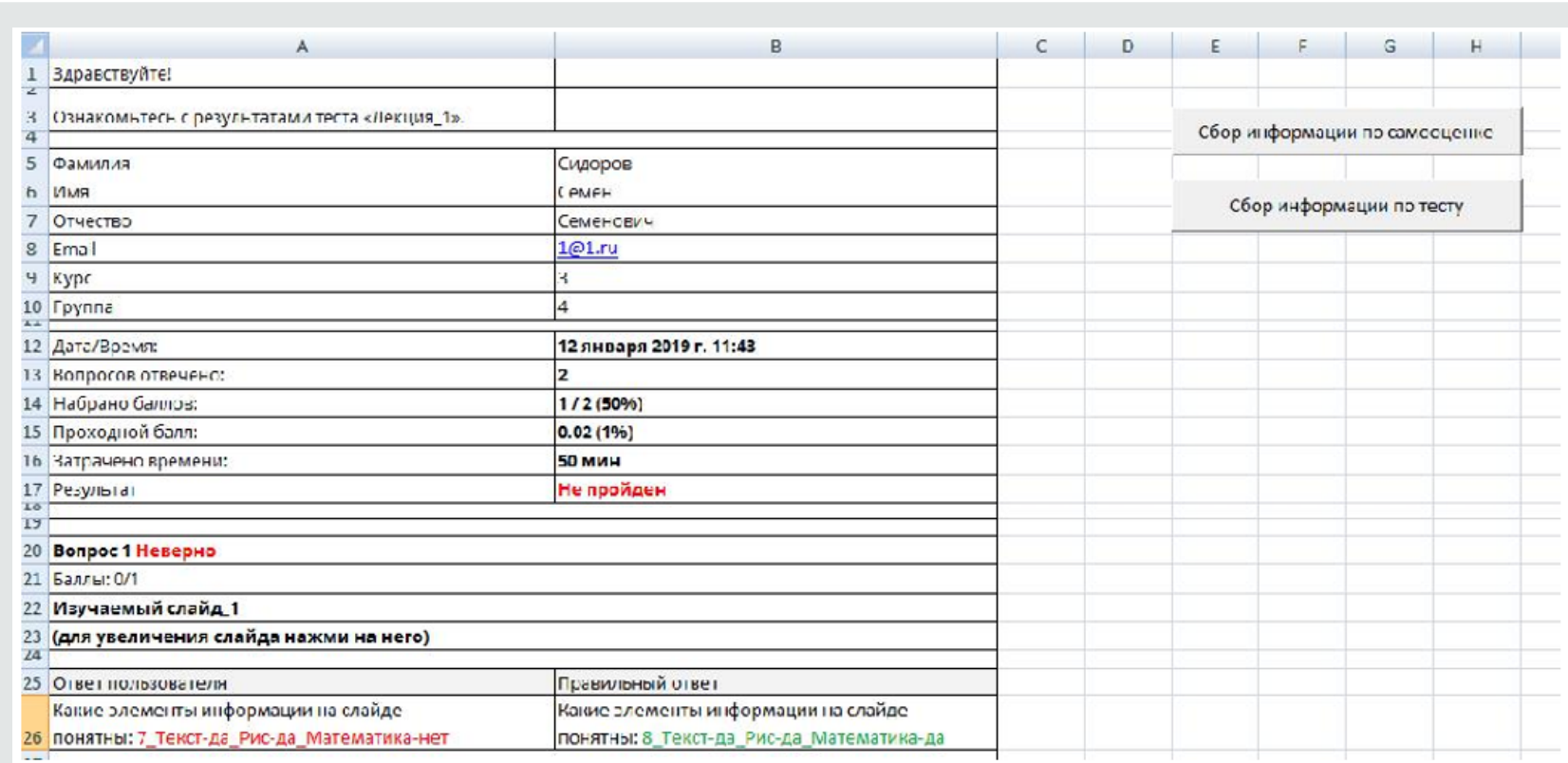

Figure 6: The results of the student's work with lecture materials in Excel-file.

Figure 7: Scale identification

\begin{tabular}{|c|c|c|c|}
\hline код & текст & рисунок & математ. \\
\hline 1 & 0 -нет & 0 -нет & 0 -нет \\
\hline 2 & 0 -нет & 0 -нет & 1-да \\
\hline 3 & 0 -нет & 1-да & 0 -нет \\
\hline 4 & 1-да & 0-нет & 0 -нет \\
\hline 5 & 0 -нет & 1-да & 1-да \\
\hline 6 & 1-да & 0 -нет & 1-да \\
\hline 7 & 1-да & 1-да & 0-нет \\
\hline 8 & 1-да & 1-да & 1-да \\
\hline
\end{tabular}

\begin{tabular}{|c|c|c|c|c|c|c|c|c|c|}
\hline A & B & c & D & E & $\mathrm{F}$ & G & H & 1 & $\mathrm{~J}$ \\
\hline Фамилия & - имя & Отчество & - Год & Месяц Г & День месяца Г & Лекция № - & Время на лекцию(мин) & $C_{1} 1 \mathrm{~V}$ & $c_{2} 2 \mathrm{~V}$ \\
\hline Сидоров & Семен & Семенович & 2019 & январь & 12 & 1 & 50 & 7 & 8 \\
\hline Сидоров & Семен & Семенович & 2019 & январь & 15 & 1 & 50 & 8 & 8 \\
\hline Сидоров & Семен & Семенович & 2019 & январь & 20 & 1 & 50 & 8 & 8 \\
\hline Сидоров & Семен & Семенович & 2019 & январь & 25 & 1 & 50 & 8 & 8 \\
\hline Сидоров & Семен & Семенович & 2019 & февраль & 8 & 1 & 50 & 8 & 8 \\
\hline Сидоров & Семен & Семенович & 2019 & февраль & 27 & 1 & 50 & 8 & 8 \\
\hline Сидоров & Семен & Семенович & 2019 & март & 11 & 1 & 50 & 8 & 8 \\
\hline Сидоров & Семен & Семенович & 2019 & март & 15 & 1 & 50 & 8 & 8 \\
\hline
\end{tabular}

Figure 8: Learner self-assessment table.

When implementing the macro, the procedure of identification (code assignment) of the degree of comprehension of the lecture materials by the learner in accordance with his answers on the information and control frame is automatically performed. The information on the student's self-assessment formalized in this way is placed in a "smart table" (Figure 8), which uses cognitive graphics to focus the teacher's attention on the expected level of his / her preparedness Having analyzed in the "smart table" MS Excel the results of self-assessment of the student's work with the lecture (the article considers the example of one frame), the teacher for each 
student or for a group of students forms an individual trajectory of its study. The subsequent results of mastering the material taking into account the proposals of the teacher according to the individual work plan, are also recorded in the table for visualization of the dynamics of the learning process. And the presence in the table of time indicators of work with the material allow to assess the true diligence of the student.

The second stage of the teacher's work is to collect and process information about the test tests of students on the materials of the course topic, which may include several lectures. Test materials are formed from a common database of "questions and answers", combining three sections: text, drawing, mathematics. The choice of specific test questions is determined by the content and structure of the frame, as well as the type of test (binary choice, choice "one of many", multiple choice, etc.). The alternation of objects in the frame window (correct and incorrect answers by section) is random. The test data is also automatically sent to the teacher's e-mail in a formalized form (Figure 9). Excel-structured e-mail data of the student's test are copied to the macro file and transferred to the "smart table" (Figures $10 \& 11$ ). The scale of identification of the degree of correctness of the student's answers to the test questions is similar to that shown in Figure 7. The difference between the content of the test results (in the mail or in an Excel-file) from the data of the student's self-assessment is a detailed indication of the teacher on the correctness or incorrectness of each student's answer to all questions (indicating the correct solution).The content of the third stage of the teacher's work is a comparative analysis of the student's self-assessment data and objective test results for decision-making on improving the educational process. Thus, the data of the "smart table" of the learner's knowledge test results show that in the testing mode the frame of the lecture material " 1 " (slide 1 ) is assimilated with the code " 2 ", which significantly differs from the student's self-assessment for January (code "7"). The teacher should pay attention to this and offer the student materials for further study of the issue. Particularly clearly the dynamics of the comparison process on the histogram (Figure 12) for lecture frame "1" (slide 1) of lecture 1, where the initial increase in the degree of assimilation of the material leads to its decline with the same inflated self-esteem.

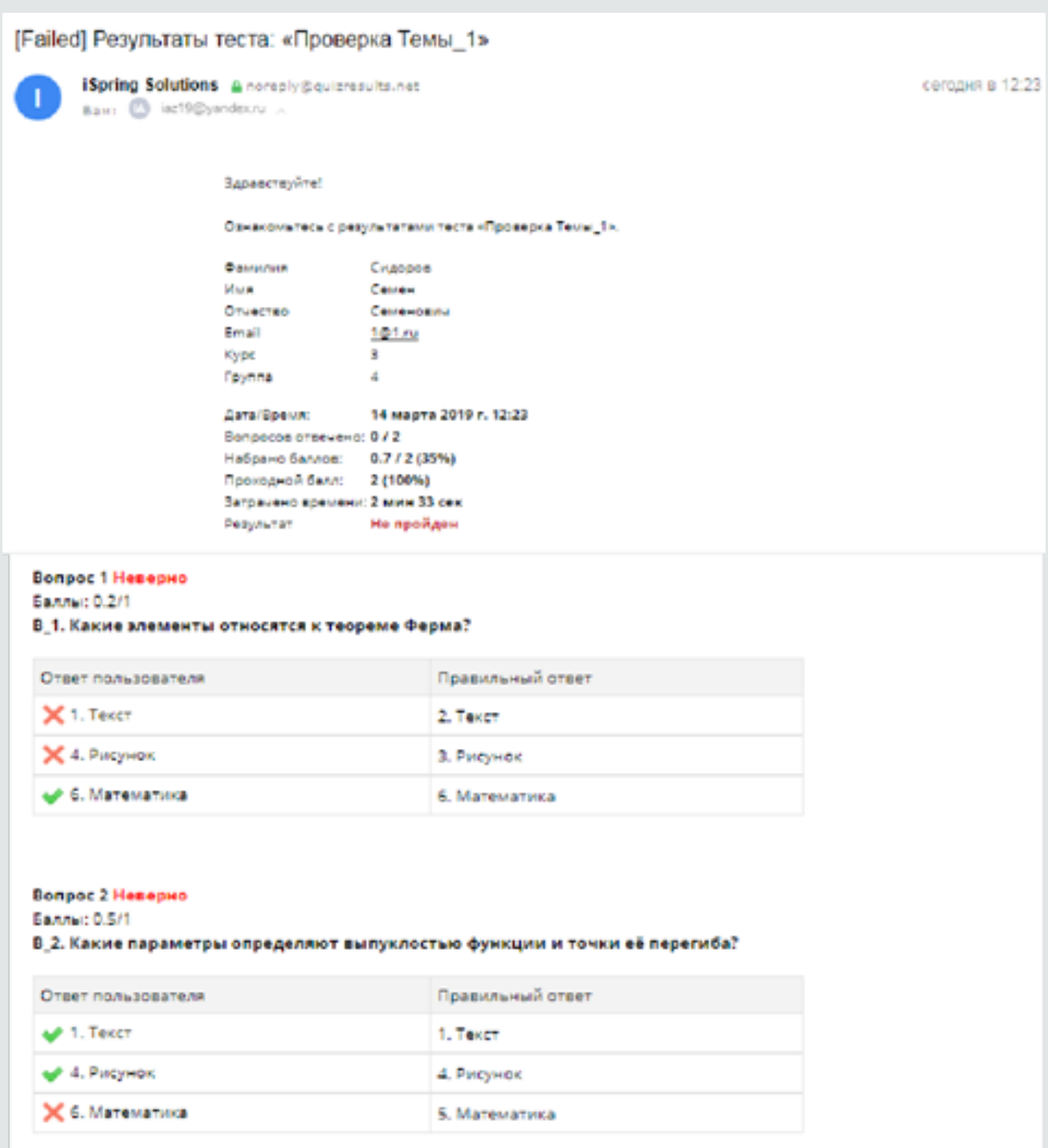

Figure 9: The results of the student's work with the test in the mail. 


\begin{tabular}{|c|c|c|}
\hline 4 & A & B \\
\hline 1 & Зацаввствуйте! & \\
\hline 3 & 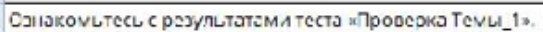 & \\
\hline & & \\
\hline 5 & Фамллия & EVAOPOE \\
\hline o & Vмन & Семен \\
\hline 7 & OІчеслие & Семенсынич \\
\hline 8 & Fmall & 1@1.1u \\
\hline y & Kypec & 3 \\
\hline 10 & Toyrna & 1 \\
\hline 12 & Дата/Время: & 27 янЕаря 2019 г. $12: 23$ \\
\hline 13 & 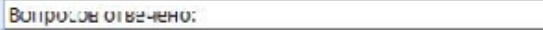 & $0 / 2$ \\
\hline 14 & H:бюранก ถิลกรกR: & $0.7 / 2(35 \%)$ \\
\hline 15 & Іісоходной ёалл: & $2(100 \%)$ \\
\hline 16 & Затранено врэиени: & 2 мин 33 сек \\
\hline 17 & РеכYILTET & Не пройден \\
\hline $\begin{array}{l}9 \\
20\end{array}$ & Benрoc 1 невсрно & \\
\hline 21 & EannLI: $0.2 / 1$ & \\
\hline 22 & В_1. Какие элементы относятся к теореме Оерме? & \\
\hline 24 & 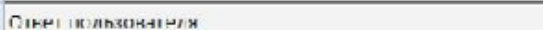 & 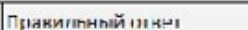 \\
\hline 25 & X, Tнкі & 7. Trk:I \\
\hline 26 & Х. Ритунок & 3. Рисуник \\
\hline 27 & Q... Маінмаіика & 5. MनI ММа IИкН \\
\hline
\end{tabular}

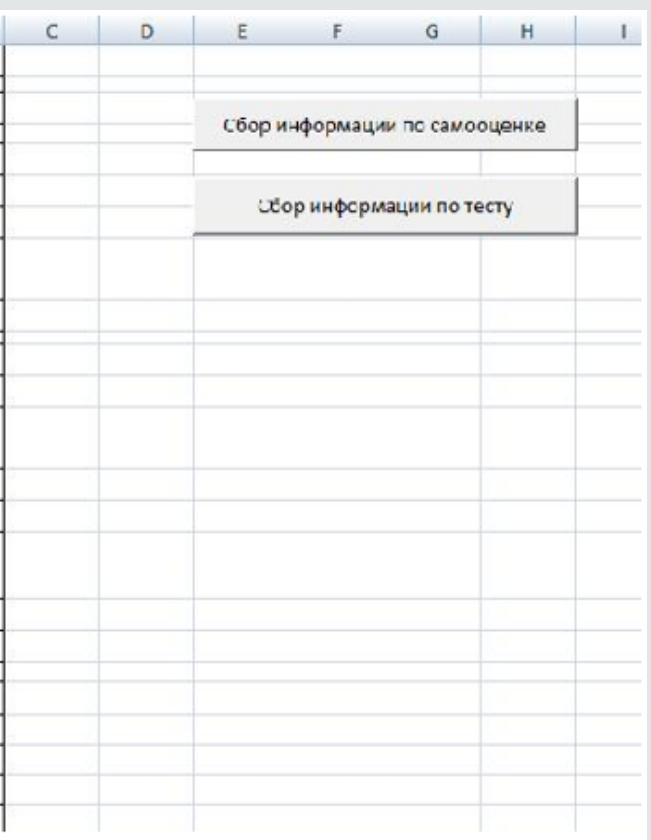

Figure 10: The results of the student with the test in Excel-file.

\begin{tabular}{|c|c|c|c|c|c|c|c|c|c|}
\hline A & B & c & D & $E$ & $\mathrm{~F}$ & G & H & 1 & 1 \\
\hline Фамилия & - Имя & - Отчество & - год & Месяц Г & День месяца & Тест поЛекция - & Время на тест(мин) & F & C $22=$ \\
\hline Сидоров & Семен & Семенович & 2019 & январь & 27 & 1 & 2 & 2 & 7 \\
\hline Сидоров & Семен & Семенович & 2019 & февраль & 15 & 1 & 2 & 7 & 7 \\
\hline Сидоров & Семен & Семенович & 2019 & март & 20 & 1 & 2 & 6 & 5 \\
\hline
\end{tabular}

Figure 11: Table of assessment of the student on the results of the test.

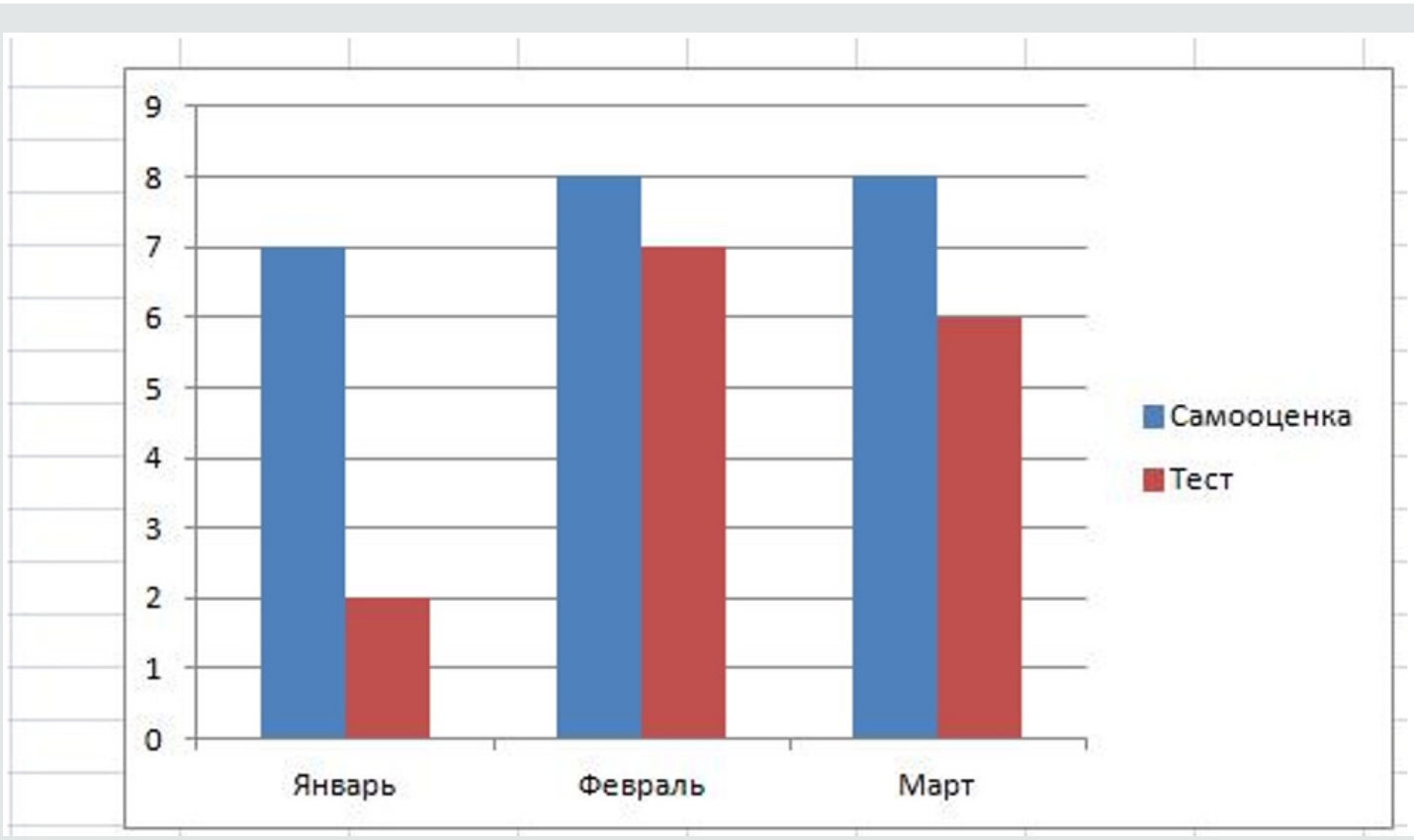

Figure 12: Example of dynamics of assessment and self-assessment of learner's knowledge (slide 1).

Reducing the level of knowledge of the student on an objective assessment (test) while maintaining this level of selfassessment can be associated with often practiced in the student environment mechanical memorization of the material, leading to the formal assimilation of knowledge by sequentially memorizing individual parts of the material without relying on the semantic relationship between them. Semantic memorization is based on the understanding of meaning, awareness of relations and internal 
logical connection between the parts of the memorized material and between this material and previous knowledge. The teacher should know and constantly remind students that mechanical memorization is uneconomical, it requires much more time than semantic memorization, besides, mechanically memorized material is forgotten much faster. Thus, the information technology approach of the authors to the organization and control of training, although it does not provide, of course, the transformation of the entire education system with the use of modern information technologies, but nevertheless offers a way to individualize and intensify the educational process by transition to the use of elements of the theory of artificial intelligence ("smart table") in order to ensure quality training of qualified personnel of the XXI century. However, it is necessary to understand that the use of modern IT-technologies to improve the efficiency of education at the University in the context of digitization of the education system as a whole should be based not only on the achievement of universal digital literacy, but also on the semantic approach to the assimilation of knowledge.

\section{Conclusion}

It should be noted that the changing world imposes radically new requirements for the content of education: it should be extremely saturated with fundamental values, knowledge and meaning. At the same time, the basis, rigor, even pedantry in the selection and systematization of the studied material as opposed to lightweight, kaleidoscopic, opportunistic are certainly important. The constants of education, its fundamental cultural and scientific core are designed to help representatives of new generations not only to adapt to a rapidly changing world, but also to participate in positive changes themselves. The modernization of education is an integral part and at the same time a necessary condition for the success of the modernization of the Russian economy. We need an innovative education system that will provide training for specialists who are well versed in the current problems of the economy and find non-traditional innovative ways to solve them. Specialists who will be able to justify the development and implementation of innovative projects in the technological, information, management, social and other spheres during the research. In addition, the innovative nature of education should be the most important tool in its competition with other social institutions for influence on the younger generation. Unfortunately, at present, education ceases to play a leading role in the socialization of the younger generation, giving primacy to the means of mass information and communication, mass culture, advertising, which turn into active producers of patterns and models of behavior among young people.

\section{References}

1. (2019) Message of the President to the Federal Assembly of the Russian Federation.

2. Zhuk IA, Reznichenko AV (2018) Assessing the effectiveness of the educational process with the application of the method of analysis of hierarchies. International conference session "Public administration and development of Russia: challenges and opportunities", M: Publishing house "SCIENTIFIC LIBRARY", Russia 1: 869-884.

3. Zhuk IA, Reznichenko AV (2017) Features of the formation and use of lecture material with the use of modern information technologies. International conference session "Public administration and development of Russia: the choice of priorities" M: Publishing house "Prospect", Russia 1: 194-205.

4. Yaroslav Kuzminov (2008) Russian education-2020: model of education for innovative economy. M: Publishing house "Higher school of Economics", academic journal" education" 1: 38-39.

5. Lyz NA, Lyz AE (2012) Trends in the development of higher education. Teaching aid. N and Lisi, A. E. Lisi-Taganrog: Publishing house "Southern Federal University Institute of technology" p. 47S.

6. Manushin EA (2013) Problems and prospects of innovative development of the Russian higher education. EA Manushin M: Publishing house "Russian academic education", Informational, pedagogical, scientific and methodological publication "Professional education p. 10-13.

7. Reznichenko AV (2004) Man And education in the modern informationtechnogenic world: monograph. AV Reznichenko M: OVA RF armed forces 1: 25 .

8. (2018) You cannot just take and digitize: website of the Institute for statistical research and Economics of knowledge of the Higher school of Economics-2014.

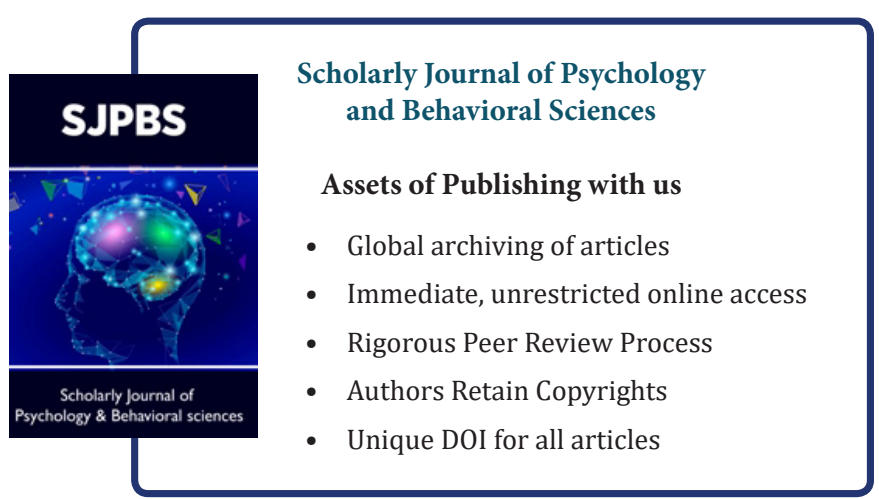

